\title{
"Ceria"
}

Jurnal Program Studi Pendidikan Anak Usia Dini

ISSN 2301-9905

Volume 8, No. 1, Juli 2018

Fakultas Keguruan dan Ilmu Pendidikan- Universitas Muhammadiyah Tangerang

\section{Upaya Meningkatkan Kemampuan Bercerita Melalui Media Gambar Seri Pada Anak Usia 5-7 Tahun}

\author{
Umini Tresna Dewi ${ }^{1}$, Evy Fitria ${ }^{2}$ \\ 1,2Program Studi Pendidikan Guru Pendidikan Anak Usia Dini \\ Fakultas Keguruan dan Ilmu Pendidikan Universitas Muhammadiyah Tangerang \\ Email : ${ }^{1}$ ut.dewi18@gmail.com, ${ }^{2}$ evifitria7@yahoo.com
}

\begin{abstract}
Abstrak
Penelitian ini bertujuan untuk mengetahui bagaimana meningkatkan kemampuan bercerita anak melalui media gambar seri. Penelitian ini dilaksanakan di TK Sunan Bonang Kelapa Dua Kabupaten Tangerang dengan subyek sebanyak 10 siswa pada semester II tahun pelajaran 2016/2017. Penelitian ini adalah penelitian tindakan kelas dan dilaksanakan dalam tiga siklus dengan empat kali pertemuan. Setiap siklus terdiri dari tahapan perencanaan, pelaksanaan tindakan, observasi dan refleksi. Pengumpulan data dilakukan dengan instrumen penelitian berupa catatan lapangan, lembar observasi, wawancara, catatan dokumentasi. Berdasarkan analisis data diperoleh hasil pada pra siklus kemampuan bercerita 8 anak kategori belum berkembang dan 2 anak kategori berkembang sesuai harapan (20)\%. Siklus I kemampuan bercerita 2 anak kategori belum berkembang, 4 anak mulai berkembang, dan 4 anak kategori berkembang sesuai harapan (40)\%. Siklus II kemampuan bercerita 3 anak kategori mulai berkembang, 4 anak kategori berkembang sesuai harapan, dan 3 anak kategori berkembang sangat baik (70)\%. Siklus III kemampuan bercerita 1 anak kategori berkembang sesuai harapan dan 9 anak kategori berkembang sangat baik $90 \%$. Berdasarkan analisa data dan pembahasan hasil penelitian, maka dapat disimpulkan bahwa penerapan atau penggunaan media gambar seri dapat meningkatkan kemampuan bercerita anak usia 5-7 tahun di TK Sunan Bonang.

Kata Kunci : Kemampuan Bercerita, Media Gambar Seri, Anak usia 5-7 tahun
\end{abstract}


"Ceria"

Jurnal Program Studi Pendidikan Anak Usia Dini

\section{Pengantar}

Anak adalah amanah dari Allah yang harus dirawat, dididik sepenuh hati, dan kita diperintahkan agar bisa menunaikan amanah dengan sebaik-baiknya. Selaku orang tua diwajibkan mampu menjaga dan menunaikan amanah yang diberikan oleh Allah kepada kita. Anak sebagai ciptaan Allah yang mulia dan memiliki berbagai keutamaan, Islam memandang bahwa sebagai keutamaan yang dimiliki anak ini sangat tergantung kepada kemampuan orang tua dalam mendidik.

Anak Usia Dini merupakan individu yang sedang mengalami proses pertumbuhan yang pesat dan fundamental bagi kehidupan selanjutnya. Pada masa ini proses pertumbuhan dan perkembangan dalam berbagai aspek fisik maupun psikis sedang mengalami masa yang cepat dalam rentang perkembangn hidup manusia. Perkembangan anak meliputi moral dan agama, kognitif, fisik motorik, sosial emosional, seni dan bahasa. Pada usia ini, salah satu aspek yang dapat dikembangkan pada anak dalam bahasa adalah kemampuan bercerita.

Penting dilakukan upaya pengembangan potensi diri anak, salah satunya pengembangan kemampuan bercerita yang dapat menentukan keberhasilan anak dimasa yang akan datang. Menurut Madyawati (2016, h. 162) mengemukakan bercerita adalah keterampilan berbicara yang bertujuan untuk memberikan informasi kepada orang lain dengan cara menyampaikan berbagai macam ungkapan, berbagai perasaan sesuai dengan apa yang dialami, dirasakan, dilihat, dan di baca. Bercerita sangatlah penting dikembangkan pada anak sejak usia dini untuk mempersiapkan kehidupan dimasa dewasanya, karena dengan bercerita anak dapat menyampaikan berbagai macam ungkapan perasaan dan keinginannya.

Salah satu pendekatan yang dilakukan pada anak usia dini untuk merangsang dan mengembangkan kemampuan bercerita anak adalah dengan kegiatan bercerita dengan menggunakan alat peraga yang menarik dan menyenagkan. Guru sebagai pendidik di sekolah harus dapat memilih dan memanfaatkan setiap kesempatan belajar untuk mengembangkan kemampuan bercerita anak.

Berdasarkan observasi yang dilakukan oleh peneliti di TK Sunan Bonang kelapa Dua 
"Ceria"

Jurnal Program Studi Pendidikan Anak Usia Dini

Kabupaten tangerang, terlihat bahwa kemampuan bercerita anak pada usia kelompok B (usia 5-7 tahun) masih belum berkembang secara optimal. Pada saat melakukan kegiatan bercerita di kelas, hanya 2 dari 10 anak yang dapat bercerita dengan baik, dan 8 anak lainnya masih perlu bimbingan dan bantuan guru.

Pada tingkat pencapaian perkembangan anak yang tercantum dalam Peraturan Menteri Pendidikan dan Kebudayaan Nomor 137 Tahun 2014 Tentang Standar Nasional PAUD, pada usia tersebut bahasa anak dalam hal bercerita sudah mencapai kemampuan diantaranya yaitu meliputi kemampuan mendengar, kemampuan memahami, kemampuan mengekspresikan diri, dan kemampuan menjawab pertanyaan yang lebih kompleks.

Kegiatan mendengarkan cerita akan memberi pengalaman belajar yang melatih pendengaran anak, sehingga anak dapat memperoleh informasi tentang budaya, dan peristiwa yang terjadi di lingkungan sekitar. Serta dapat menambah perbendaharaan kata anak. Hal ini menunjang kemampuan anak untuk berkomunikasi secara lisan dengan teman sebaya, guru maupun dengan orang tua disekitarnya. Dengan kegiatan bercerita diharapkan mampu menarik anak untuk lebih menyukai cerita. Dalam hal ini senada dengan Garis-garis Besar Program Kegiatan Belajar, Depdiknas (Dhieni dkk, 2005, h. 6.7) bahwa implementasi dari kegiatan bercerita pada pengembangan bahasa yaitu meliputi: 1) Bercerita tentang kejadian di sekitarnya secara sederhana, 2) Menjawab pertanyaan tentang cerita pendek yang sudah diceritakan guru, 3) Mengurutkan dan menceritakan isi gambar seri 4-6 gambar, 4)Bercerita tentang gambar yang dibuat sendiri, 5) Menceritakan kembali isi cerita sederhana yang sudah diceritakan oleh guru, 6) Melanjutkan cerita sederhana yang sudah dimulai guru, 7) Menceritakan gambar yang telah disediakan.

Dalam penelitian ini peneliti memilih media gambar seri untuk mengembangkan kemampuan bercerita anak. Tujuan yang ingin dicapai adalah untuk mengembangkan kemampuan bercerita anak, yaitu anak mampu memahami isi cerita dan dapat melanjutkan cerita, serta anak dapat menceritakan kembali cerita yang telah didengarnya.

Bercerita merupakan kegiatan berbahasa yang bersifat produktif. Bercerita seseorang melibatkan pikiran, kesiapan mental, keberanian, perkataan yang jelas sehingga dapat 
"Ceria"

Jurnal Program Studi Pendidikan Anak Usia Dini

dipahami oleh orang lain. Kemampuan bercerita memiliki beberapa kemampuan, antara lain yaitu kemampuan mendengar, kemampuan memahami, kemampuan mengekspresikan diri serta kemampuan menjawab. Kegiatan berceita dengan gambar seri memberikan kesempatan bagi anak untuk mengembangkan keempat kemampuan tersebut. Anak diberi kesempatan untuk bercerita dengan menggunakan gambar seri sehingga anak dapat mengekspresikan diri dan dapat bercerita di depan teman-temannya dengan percaya diri, dan anak juga dapat berkomunikasi dengan menjawab pertanyaan yang lebih kompleks seputar cerita tersebut.

Media gambar seri tersusun dari kertas lebar memanjang yang berisi beberapa buah gambar (Kemendiknas, 2010). Gambar-gambar tersebut berhubungan satu sama lain sehingga merupakan satu rangkaian cerita. Setiap gambar diberi nomor urut sesuai dengan urutan jalannya cerita. Media gambar seri cocok untuk melati keterampilan berbahasa serta keterampilan ekspresi (berbicara, bercerita). Dengan gambar seri anak diharapkan dapat memperoleh konsep tentang sebuah cerita degnan topik tertentu. Gambar seri dengan rangkaian gambar ini menceritakan suatu peristiwa serta berguna untuk menyampaikan pengetahuan, keterampilan, dan menanamkan sikap kepada anak usia dini.

Dhieni dan Etal (Madyawati, 2016, h. 211) menyatakan bahwa terdapat beberapa manfaat bercerita dengan menggunakan media gambar seri bagi anak, sebagai berikut: (1) Melatih daya serap atau daya tangkap anak; (2) Melatih daya pikir anak; (3) Melatih daya konsentrasi anak; (4) Mengembangkan daya imajinasi anak; (5) Menciptakan situasi yang menggembirakan; (6) Membantu perkembangan bahasa anak dalam berkomunikasi.

Bercerita dengan media gambar seri adalah kegiatan yang menarik dan menyenangkan bagi anak. Media gambar seri tersusun dari kertas lebar memanjang yang berisi beberapa buah gambar. Gambar-gambar tersebut berhubungan satu sama lain sehingga merupakan satu rangkain cerita sesuai dengan tema tertentu. Bagi anak usia dini, proses pembelajaran kegiatan bercerita dengan media gambar seri dapat meningkatkan kemampuan bercerita anak, karena pada kegiatan ini anak dapat memahami isi cerita 
"Ceria"

Jurnal Program Studi Pendidikan Anak Usia Dini

dan dapat bercerita sesuai dengan ekspresinya masing-masing. Anak dapat berkomunikasi dan dapat menjawab pertanyaan yang lebih kompleks.

Dengan demikian, kegiatan bercerita dengan media gambar seri dapat membantu meningkatkan kemampuan bercerita anak. Melalui media gambar seri, anak-anak merasa lebih tertarik untuk mendengarkan cerita dengan baik dan dapat menceritakannya kembali di depan teman-temannya sesuai dengan ekspresinya sehingga kemampuan bercerita anak dapat meningkat dan berkembang sesuai harapan.

\section{Metode}

Metode penelitian yang digunakan dalam penelitian ini adalah Penelitian Tindakan Kelas (PTK), dengan subjek penelitian yaitu anak kelompok B (usia 5-7 tahun) di TK sunan Bonang Kelapa Dua Kab Tangerang. Menurut Wihardit dan Wardhani (2014, h.1.4), penelitian Tindakan Kelas (PTK) adalah penelitian tindakan yang dilakukan oleh guru di dalam kelasnya sendiri melalui refleksi diri, dengan tujuan untuk memperbaiki kinerjanya sebagai guru, sehingga hasil belajar siswa meningkat. Arikunto dkk (2015, h.124) menjelaskan penelitian tindakan kelas (PTK) adalah penelitian tindakan yang dilakukan oleh guru dengan tujuan memperbaiki mutu praktik pembelajaran di kelasnya. PTK berfokus pada proses pembelajaran yang terjadi di kelas, dilakukan pada situasi alami. Dalam penelitian ini kolaborasi dilakukan antara peneliti dan guru kelas, dimana peneliti bertindak sebagai observer dan guru bertindak sebagai pelaksana tindakan. Dalam Penelitian Tindakan Kelas ini, tindakan yang dilakukan adalah meningkatkan kemampuan bercerita melalui media gambar seri pada anak usia 5-7 tahun, dengan fokus pada aspek-aspek kemampuan bercerita, yaitu berupa kemampuan mendengar, kemampuan memahami, kemampuan mengekspresikan diri, serta kemampuan menjawab.

Desain penelitian yang digunakan adalah model Kemmis dan Taggart, yaitu dilakukan dalam tiga siklus dan empat tindakan/pertemuan pada setiap siklusnya. Tahapan dalam penelitian ini adalah perencanaan, pelaksanaan tindakan, pengamatan dan refleksi. Instrumen yang digunakan dalam penelitian ini yaitu berupa lembar penilaian berupa daftar checklist, catatan wawancara, catatan lapangan serta dokumentasi. Teknik 
"Ceria"

Jurnal Program Studi Pendidikan Anak Usia Dini

analisis data yang digunakan adalah berupa data kuantitatif dan data kualitatif.

\section{Hasil Dan Pembahasan}

Peningkatan kemampuan bercerita anak dalam penelitian ini dilakukan dengan menerapkan kegiatan bercerita dengan media gambar seri dalam tiga siklus, setiap siklus terdiri dari empat pertemuan. Kemampuan bercerita anak diukur berdasarkan empat indikator yaitu kemampuan mendengar, kemampuan memahami, kemampuan mengekspresikan diri dan kemampuan menjawab.

Penerapan kegiatan bercerita dengan media gambar seri yang dilakukan peneliti menggunakan media serta membahas tema yang berbeda pada setiap siklus. Pada siklus I tema yang dibahas adalah binatang dengan sub tema binatang ternak. Media yang digunakan adalah gambar seri dengan 2 gambar dan dengan cerita yang berjudul "Bebek Berenang" .

Hasil pengamatan pada siklus I menunjukkan ada beberapa anak dalam kegiatan melanjutkan cerita masih harus dibantu oleh guru selama kegiatan, begitu pula dalam proses kegiatan tanya jawab. Ada pula anak yang mampu melanjutkan cerita walaupun dalam menyampaikannya masih di bantu oleh guru .

Tabel 1

Hasil Observasi Kemampuan Bercerita Anak Siklus I

\begin{tabular}{ccccccccccccc}
\hline \multirow{2}{*}{ NAMA } & \multicolumn{1}{c}{ INDIKATOR } & \multicolumn{1}{c}{ JUMLAH } \\
& & 1 & & 2 & & & 3 & & 4 & F & $\%$ & KET \\
\hline NY & 4 & 3 & 3 & 3 & 3 & 3 & 3 & 3 & 3 & 28 & $77 \%$ & BSH \\
HF & 4 & 3 & 3 & 2 & 2 & 2 & 3 & 3 & 3 & 25 & $69 \%$ & MB \\
FJR & 3 & 3 & 3 & 2 & 2 & 3 & 3 & 3 & 3 & 25 & $69 \%$ & MB \\
GLN & 3 & 3 & 2 & 2 & 2 & 2 & 3 & 3 & 3 & 23 & $63 \%$ & MB \\
PTR & 3 & 4 & 3 & 3 & 3 & 3 & 3 & 3 & 3 & 28 & $77 \%$ & BSH \\
MYL & 2 & 4 & 3 & 3 & 3 & 3 & 3 & 3 & 3 & 28 & $77 \%$ & BSH \\
RDH & 3 & 3 & 3 & 2 & 2 & 2 & 2 & 2 & 2 & 20 & $55 \%$ & BB \\
RQ & 3 & 4 & 3 & 3 & 3 & 3 & 3 & 3 & 3 & 28 & $77 \%$ & BSH \\
STR & 3 & 2 & 2 & 2 & 2 & 2 & 2 & 2 & 2 & 19 & $53 \%$ & BB \\
RF & 3 & 3 & 3 & 2 & 2 & 3 & 3 & 3 & 2 & 24 & $66 \%$ & MB \\
JUMLAH & & & & & & & & & & 248 & & \\
\hline
\end{tabular}


"Ceria"

Jurnal Program Studi Pendidikan Anak Usia Dini

Berdasarkan tabel 1 di atas terlihat bahwa kemampuan bercerita anak pada siklus I telah mencapai persentase sebesar $40 \%$, yaitu dari 10 anak ada 4 anak yang skor kemampuan berceritanya telah mencapai indikator keberhasilan yang telah ditentukan. Anak mengalami peningkatan walaupun sebagian besar anak belum memenuhi kriteria dalam setiap indikator yang diukur.

Berdasarkan temuan tersebut, peneliti melakukan perbaikan pada siklus II agar hasil yang dicapai dapat lebih optimal. Peneliti menggunakan media gambar seri untuk digunakan anak agar anak dapat bercerita dan percaya diri dalam menyampaikan ceritanya. Pada siklus II tema yang dibahas adalah binatang dengan sub tema binatang darat. Media yang digunakan adalah media gambar seri dengan 3 gambar dan dengan cerita yang berjudul "Kancil menceri timun"

Berdasarkan pengamatan yang dilakukan pada siklus II, terlihat beberapa anak sudah menunjukkan perkembangan yang sangat baik, anak sudah dapat menjawab pertanyaan, melanjutkan cerita, dan menceritakan kembali isi cerita, namun masih ada anak yang dibantu dalam menyampaikan ceritanya. Ada pula anak yang belum berani bercerita di depan teman-temannya dengan menggunakan gambar seri.

Tabel 2

Hasil Observasi Kemampuan Bercerita Anak Siklus II

\begin{tabular}{ccccccccccccc}
\hline \multirow{2}{*}{ NAMA } & \multicolumn{1}{c}{ INDIKATOR } & \multicolumn{1}{c}{ JUMLAH } & \multirow{3}{*}{ KET } \\
& \multicolumn{1}{c}{} & & & 2 & & & 3 & & 4 & F & $\%$ & \\
\hline NY & 4 & 4 & 4 & 4 & 3 & 3 & 3 & 3 & 3 & 31 & $86 \%$ & BSB \\
HF & 4 & 4 & 3 & 3 & 3 & 3 & 3 & 3 & 3 & 29 & $80 \%$ & BSH \\
FJR & 4 & 4 & 3 & 3 & 3 & 3 & 3 & 3 & 3 & 29 & $80 \%$ & BSH \\
GLN & 3 & 3 & 3 & 2 & 2 & 3 & 3 & 3 & 3 & 25 & $69 \%$ & BSH \\
PTR & 4 & 4 & 4 & 4 & 3 & 3 & 3 & 3 & 3 & 31 & $86 \%$ & BSB \\
MYL & 4 & 4 & 4 & 3 & 3 & 3 & 3 & 3 & 4 & 31 & $86 \%$ & BSB \\
RDH & 2 & 3 & 3 & 3 & 2 & 3 & 3 & 3 & 3 & 25 & $69 \%$ & MB \\
RQ & 4 & 4 & 3 & 3 & 3 & 3 & 3 & 3 & 3 & 29 & $80 \%$ & BSH \\
STR & 3 & 3 & 3 & 2 & 2 & 3 & 3 & 3 & 3 & 25 & $69 \%$ & MB \\
RF & 3 & 4 & 3 & 3 & 3 & 3 & 3 & 3 & 3 & 28 & $77 \%$ & BSH \\
JUMLAH & & & & & & & & & & 283 & & \\
\hline
\end{tabular}


"Ceria"

Jurnal Program Studi Pendidikan Anak Usia Dini

Dari data pada tabel 2 diketahui bahwa pada siklus II terjadi peningkatan persentase keberhasilan sebesar 30\%, yaitu dari hasil pada siklus I sebesar $40 \%$ kemudian setelah diberi tindakan pada siklus II meningkat menjadi 70\%. Dari 10 anak, ada 7 anak yang skor kemampuan berceritanya telah mencapai indikator keberhasilan yang ditentukan. Artinya, anak mengalami peningkatan walaupun beberapa anak belum memenuhi kriteria dalam setiap indikator yang diukur.

Berdasarkan temuan di atas, peneliti kembali melakukan perbaikan pada siklus III agar dapat mencapai hasil yang lebih baik. Peneliti menggunakan media gambar seri untuk digunakan anak agar anak dapat bercerita dan percaya diri dalam menyampaikan ceritanya. Pada siklus III tema yang dibahas adalah binatang dengan sub tema binatang unggas. Media yang digunakan adalah media gambar seri dengan 4 gambar dan dengan cerita yang berjudul "Cedrawasih dan burung gagak".

Berdasarkan pengamatan yang dilakukan pada siklus III, terlihat sebagian besar anak sudah dapat mendengar dan memahami cerita yang telah didengarnya. Anak juga sudah dapat melanjutkan cerita dan menceritakan kembali isi cerita dengan baik, meskipun masih ada satu anak yang masih dibantu oleh guru. Secara keseluruhan anak-anak juga sudah mampu berkomukikasi dengan menjawab pertanyaan tentang seputar cerita tersebut, meskipun masih ada satu orang anak yang masih diarahkan oleh guru.

Tabel 3

Hasil Observasi Kemampuan Bercerita Anak Siklus III

\begin{tabular}{cccccccccccccc}
\hline \multirow{2}{*}{ NAMA } & \multicolumn{1}{c}{ INDIKATOR } & \multicolumn{4}{c}{ JUMLAH } & \multicolumn{3}{c}{ KET } \\
& \multicolumn{1}{c}{} & & & 2 & & & 3 & & 4 & F & $\%$ & \\
\hline NY & 4 & 4 & 4 & 4 & 4 & 4 & 3 & 4 & 4 & 35 & $97 \%$ & BSB \\
HF & 4 & 4 & 4 & 4 & 4 & 4 & 4 & 3 & 3 & 34 & $94 \%$ & BSB \\
FJR & 4 & 4 & 4 & 4 & 4 & 3 & 3 & 4 & 4 & 34 & $94 \%$ & BSB \\
GLN & 4 & 4 & 4 & 4 & 3 & 3 & 3 & 4 & 3 & 32 & $88 \%$ & BSB \\
PTR & 4 & 4 & 4 & 4 & 4 & 3 & 4 & 4 & 4 & 35 & $87 \%$ & BSB \\
MYL & 4 & 4 & 4 & 4 & 4 & 3 & 4 & 4 & 3 & 34 & $84 \%$ & BSB \\
RDH & 4 & 4 & 3 & 3 & 3 & 3 & 3 & 4 & 3 & 30 & $83 \%$ & BSB \\
RQ & 4 & 4 & 4 & 4 & 4 & 4 & 3 & 4 & 4 & 35 & $97 \%$ & BSB \\
STR & 3 & 3 & 3 & 3 & 3 & 3 & 3 & 3 & 3 & 27 & $75 \%$ & BSH
\end{tabular}


"Ceria"

Jurnal Program Studi Pendidikan Anak Usia Dini

\begin{tabular}{ccccccccccccc} 
RF & 4 & 4 & 4 & 4 & 3 & 3 & 3 & 4 & 4 & 33 & $91 \%$ & BSB \\
JUMLAH & & & & & & & & & & 329 & & \\
\hline
\end{tabular}

Dari data pada tabel 3 diketahui bahwa kemampuan bercerita anak pada siklus III telah meningkat dan mencapai indikator keberhasilan dengan persentase sebesar $90 \%$. Dari 10 anak, sudah ada 9 anak yang skor kemampuan berceritanya telah mencapai indikator keberhasilan yang ditentukan. Artinya, kemampuan bercerita anak mengalami peningkatan dan semakin baik walaupun masih ada anak yang belum memenuhi kriteria dalam indikator yang diukur. Dengan adanya peningkatan pada indikator kemampuan bercerita tersebut, maka peneliti menganggap hasil dari siklus III ini telah sesuai dengan hipotesis yang diajukan.

Berdasarkan paparan hasil data terkait kemampuan bercerita anak di atas dapat diketahui bahwa kegiatan bercerita dengan media gambar seri memberikan kesempatan pada anak untuk mengembangkan kemampuan berceritanya, dan dapat berkomuniksi dengan menjawab pertanyaan tentang isi cerita tersebut. Proses kegiatan pembelajaran melalui kegiatan bercerita dengan gambar seri lebih menarik dan menyenangkan bagi anak. Media yang digunakan dapat memotivasi anak untuk mengekspresikan dirinya dalam menyampaikan ceritanya.

\section{Kesimpulan}

Berdasarkan hasil penelitian yang dilakukan selama tiga siklus dengan media gambar seri untuk meningkatkan kemampuan bercerita pada anak usia dini, dapat diambil kesimpulan bahwa penerapan media gambar seri dapat meningkatkan kemampuan bercerita anak usia 5-7 tahun di TK Sunan Bonang Kelapa Dua Kabupaten Tangerang. Peningkatan kemampuan bercerita anak dapat dilihat dari kondisi awal bercerita anak kelompok B yang belum berkembang dengan optimal, setelah diberi tindakan pada siklus I kemudian meningkat menjadi 40\%. Kemudian pada siklus II meningkat menjadi 70\%, dan pada siklus III meningkat lagi menjadi 90\%. Kemampuan bercerita anak mengalami peningkatan setelah diberikan tindakan kegiatan bercerita dengan menggunakan media gambar seri yang menarik bagi anak. Kegiatan bercerita memberikan kesempatan anak 
"Ceria"

Jurnal Program Studi Pendidikan Anak Usia Dini

untuk menjawab pertanyaan, melanjutkan cerita, dan menceritakan kembali isi cerita di depan guru dan teman-temannya. Sebagian besar anak mampu melakukan kegiatan bercerita sesuai dengan aspek-aspek bercerita yaitu kemampuan mendengar, kemampuan memahami, kemampuan mengekspresikan, diri dan kemampuan menjawab.

Berdasarkan kesimpulan di atas, ada beberapa hal penting yang dapat ditindak lanjuti yaitu: 1) Bagi sekolah, hendaknya dapat melakukan penerapan kegiatan bercerita sebagai bagian dari pembelajaran bahasa pada anak, dan agar lebih menyiapkan sarana dan prasarana yang mendukung kemampuan pembelajaran bahasa sehingga dapat meningkatkan bercerita anak lebih optimal; 2) Bagi guru hendaknya menciptakan proses pembelajaran yang lebih kondusif, nyaman dan menyenangkan, menyiapkan media yang bertujuan meningkatkan kemampuan bercerita pada anak sehingga dapat termotivasi dengan baik; 3) Peneliti selanjutnya, peneliti selanjutnya diharapkan memperhatikan yang berkenaan dengan penggunaan media gambar seri untuk dapat mengembangkan kemampuan anak pada aspek perkembangan anak yang lain, selain bahasa.

\section{Daftar Acuan}

Arikunto, Suharsimi dkk. (2015). Penelitian Tindakan Kelas. Jakarta: Bumi Aksara.

Dhieni, Nurbaini dkk. (2005). Metode Pengembangan Bahasa. Jakarta: Universitas Terbuka

Peraturan Menteri Pendidikan dan Kebudayaan Nomor 137 Tahun 2014 Tentang Standar Nasional Pendidikan Anak Usia Dini.

Madyawati, Lilis. (2016). Strategi Pengembangan Bahasa Pada Anak. Jakarta: Prenandamedia Group.

Wihardit \& Wardhani (2014). Kurikulum Pendidikan Anak Usia Dini. Jakarta: Universitas Terbuka. 